\title{
"Assembled as one man": the councils of Henry II and the political community of England
}

\author{
"Reunidos como um homem": os conselhos de Henrique II \\ e a comunidade política da Inglaterra
}

José Manuel Cerda Costabal

Universidad Gabriela Mistral, Santiago, Chile

\begin{abstract}
The study of parliamentary origins for England - and other kingdoms - has traditionally concentrated on aspects such as the social composition of assemblies and territorial representation. It has been argued that parliamentary assemblies were born when the three estates of medieval society were summoned to meet the king at feudal councils. However, such an approach has led to some anachronistic conclusions that have overlooked the importance of the presence of the political community, the communitas or universitas regni at these assemblies as a key phenomenon to understanding parliamentary origins. Such community was the body of nobles, assembled as one at councils not because they represented the kingdom, but because they were the kingdom.
\end{abstract}

KEYWORDS: Assemblies. Henry II. Medieval England. Parliament.

RESUMO: O estudo das origens parlamentares da Inglaterra - e de outros reinos - tem se concentrado tradicionalmente em aspectos como a composição social das assembleias e a representação territorial. Argumentou-se que as assembleias parlamentares nasceram quando os três estamentos da sociedade medieval foram convocados para se encontrar com o rei nos conselhos feudais. Contudo, tal abordagem levou a algumas conclusões anacrônicas que negligenciaram a importância da presença da comunidade política, das communitas ou universitas regni nessas assembleias como um fenômeno chave para compreender as origens parlamentares. Tal comunidade era o corpo de nobres, reunidos como um nos conselhos, não porque representassem o reino, mas porque eram o reino.

PALAVRAS-CHAVE: Assembleias. Enrique II. Inglaterra medieval. Parlamento.

\footnotetext{
* Professor da Universidad Gabriela Mistral, Santiago, Chile. Doutor em História pela University of New South Wales, Sydney, Austrália. E-mail: joecerda@gmail.com. Orcid: http://orcid.org/0000-0002-6175-774X
} 
Just as colloquia were generally identified by the transaction of diplomatic business and the presence of two or more rulers, and church councils were singled out by ecclesiastical business and the predominant presence of the clergy, the assemblies of the realm treated the business concerning the king and the kingdom, and were accordingly attended by the political community of the realm.

When the chronicles report that all the nobles came to meet the king at a council, they probably referred to those who had been summoned, some of whom were unable to attend. This factor distinguishes the composition of assemblies, which comprised all those who were expected to provide counsel, from their attendance, which is concerned instead with those who actually came to the meeting. This distinction may further clarify, as we have indicated, the mismatch that often occurs between the information provided in the narrative sources and the witness lists of the official records.

Our study will commence with the royal court, the core of every conciliar gathering, and the king's entourage: his family, regular courtiers, and some of the members of the household who would have attended assemblies. Secondly, we will offer some thoughts on the development of the communitas regni, and then on the attendance of ecclesiastical and lay magnates at assemblies. Finally, the occasional presence of knights and townsmen will be treated to explain some changes that will gain importance in the composition of royal assemblies in the thirteenth century.

At the Council of Woodstock in 1163, the archbishop of Canterbury challenged the king's proposal to raise a new tribute called the sheriff's aid, probably on the basis that such payment was likely to fill the royal coffers instead of assisting county administration. Becket's defiance was not simply a setback for Henry's financial strategies, but more gravely perhaps, it was a public humiliation in front of the king's nobles assembled in council. According to the vernacular verses of Guernes de Pont-Sainte-Maxence, the archbishop was persuaded to comply with the king's demands and accept the customs by a papal letter brought by an abbot named Philippe de l'Aumone, who also convinced the primate to meet the king at Woodstock:

There they made him make his promise to the king, and concede that he would keep his customs in good faith, loyally; for he did not expect to hear them mentioned again. The king answered him: "If you wish to consent, you must demonstrate the fact in the presence of all my barons. They have all heard how you have opposed me. If you intend to stand by the agreement you have made, summon all the clergy and I will summon my barons; there shall be no delay. There, in the presence of all of them, declare what you have granted to me" (THOMAS, 2002, p. 80).

The passage most clearly illustrates the public significance acquired by royal councils in this period. Had Becket's opposition been simply a matter of policy, a private settlement would have perhaps satisfied the king, but since the dispute had been aired to the political community of the kingdom at a council, Henry's insulted pride would settle for nothing less than a formal submission in front of tuz mes barons, according to Guernes, in the presence of all his barons assembled. In fact, the Icelandic prose of the Thómas Saga Erkibyskups explains that as the king and the archbishop "happened to dissent in a public 'parliament', so their peace must come about in the same manner" (MAGNUSSON, 1875, v. I, p. 161). As indicated in previous chapters, royal councils gradually ceased to be an occasional enlargement of the curia regis and developed towards becoming assemblies of the realm. Several of these meetings were accordingly identified by the 
sources as "general", not only because they were public occasions for kingdom-wide consultation and the discussion of matters concerning the king and the kingdom, but also because they were attended by the universitas regni or the political community of the realm, without which neither the counsel given nor the business discussed could claim to be truly general or territorial. Bryce Lyon has argued that the king considered the trial of an archbishop to be such a serious matter that in 1164, "a feudal court representative of the realm was handing down the judgment" (LYON, 1960, p. 246). It is certainly more appropriate to refer to the meeting at Northampton as a general council than a feudal court. These were still royal assemblies and the king's court continued to be the heart of every conciliar occasion, but likewise the parliaments of the following century too were royal assemblies where the king's court played a predominant role in the proceedings.

Since it was an issue that concerned the entire political community of England and required, therefore, the counsel and audience of all the nobles, the Becket dispute could not have been resolved anywhere but in a general council of the realm. An ecclesiastical council or a private meeting with the king and his court were not public enough to treat a matter of such importance, for neither gathering would have assembled the community of the realm. This community is beginning to take shape in this period, and it is only in the thirteenth century that it reaches some legal and political recognition. The communitas regni was often associated by constitutional historians with the three estates of society, but in the twelfth century it is likely that commune consilium would have normally referred to consultation and agreement between the king and the baronage. Henry de Bracton indicates in his thirteenth-century treatise that the universitas regni and the baronagium may restrain the actions of a tyrannical monarch:

If it is the prince or king or another who has no superior except God, the remedy by assize will not lie against him; there will only be opportunity for a petition, that he correct and amend his act. If he fails so to do, let it suffice him for punishment that he await God the avenger, who says, vengeance is mine and I will repay, unless one says that the community of the realm and his baronage may and ought to do this in the king's own court (WOODBINE, 1968-1977, v. 3, p. 43)1.

In regards to the election of King John, for instance, Hubert Walter said, according to the chronicle of Mathew Paris, "noverit discretio vestra, quod nullus praevia ratione alii succedere habet in regum, nisi ab universitate regni unanimiter, invocate Spiritus gratia, electus [...]” (LUARD, 1872-1884, v. 2, p. 454-455)².

In reference to the nature of representation at the first parliaments, Alec Myers has indicated that "juridical theory ordinarily conceived of the nobles as representing, in their capacity as territorial lords, the whole population of what was still a predominantly agrarian society" (MYERS, 1955, p. 26). The lay and ecclesiastical nobles were not summoned to assemblies as representatives of their dioceses, counties, shires, and their baronies, nor did they speak on behalf of their faithful or vassals. Such misconception would imply the prevalence of proto-democratic representation and would thus assume that all free inhabitants of the kingdom were entitled to participate in the political discussions concerning the monarchy and the kingdom, either in person or by proxy. The praesules and proceres of the kingdom were summoned by the monarchs to attend royal assemblies not as representatives, but as potentiores, a functional expression of their political and religious influence, military and economic power, as well as their social status. They had the duty of providing counsel and the right of discussing the general affairs of the kingdom at assemblies, 
not because they represented the community of the realm, but because they were the community of the realm. According to Hody, the term proceres used in connection with the parliaments of the thirteenth century, "must be understood as the chief of the commonalty, since the earls and barons were at that time the whole nobility" (HODY, 1701, p. 221), while Richardson and Sayles have argued that the "commune" was "the group of conspiratorial prelates, earls and barons who regarded themselves as representing the 'community' of England” (RICHARDSON; SAYLES, 1989, p. 69-70). The dispute between the bishops and the barons at the Council of Northampton concerning the conviction of Thomas Becket groups lay and ecclesiastical nobles into one community, when they were assembled at councils. William FitzStephen records the following dialogue between the nobles when the king demanded the pronouncement of a sentence:

The barons said, "You bishops ought to pronounce sentence. This does not concern us. We are laymen, you are ecclesiastics like him, his fellow priests and fellow bishops". To this one of the bishops replied, "No, this is your duty, not ours, for this is a secular judgment, not an ecclesiastical one. We sit here not as bishops but as barons. Here we are barons just like you" (ROBERTSON, 1875-1885, v. 3, p. 52).

It could be suggested that many meetings of the Anglo-Saxon royal assembly looked rather like ecclesiastical gatherings because churchmen and church business often predominated. The preponderance of ecclesiastical presence at the sessions of the Witan is also revealed in charters and diplomas linked to the meetings, many of which qualified these councils as "synodal" and often witnessed by several bishops and abbots ${ }^{3}$. Earls were summoned mainly because they were royal appointees and the prelates attended the meetings in lieu of their spiritual status. As Stenton has explained, "the bishops, abbots, and earls attended in virtue of offices which they held by a royal grant; the priests belonged to the king's household; the thegns were present in obedience to a royal summons" (STENTON, 1971, p. 553) ${ }^{4}$. After the Norman invasion, all of England became royal property and those entrusted with the administration of land accordingly became the king's tenants. This tenurial relationship came with a number of mutual obligations, one of which is believed to be the duty of tenants to provide counsel to the king at assemblies. According to Ronald Butt, therefore, the main difference between the composition of the Witan and the Norman council is that the latter "was a baronial assembly of tenants-in-chief, even prelates now being present principally in their capacity as tenants" (BUTT, 1989, p. 21). This might explain why the episcopal participation at Northampton in 1164 was not to be singled out, and why the bishops claimed to have been present at the council by virtue of their property rather than their office.

According to Bryce Lyon, "the Angevins preferred to convoke special great councils to consider issues pertinent to the whole realm [...] composed of all the royal vassals, that is, the baronage" (LYON, 1960, p. 246). Henry certainly wanted the archbishop of Canterbury to apologise in the presence of "all the barons", as Guernes records, but it is altogether improbable that every single one of the king's barons was present at the councils convened for the trial. It is also difficult to determine exactly what the term "barons" entails. It is therefore relevant to determine who expected to be summoned and who was actually present at royal councils between 1155 and 1188 with a view to establishing a correspondence between the increasingly public character of assemblies and general or territorial attendance. This information can only be sought in an analysis of chronicle passages and the witness lists of charters connected with conciliar activity. 
English assemblies which met before the 1150s were well attended, and thus the changes in the composition of councils throughout the twelfth century are not substantial. Interestingly, however, while the attendance at most English councils after the 1150s is explicitly identified by the chronicles as general or as gathering the entire kingdom, such descriptions are rarely employed by the narrative sources for the assemblies of Henry I and Stephen. Phrases such omnes nobiles, universis or omnibus in regni and nobiles totius Anglie, are used by English chronicles to describe those summoned and congregated at more than half of Henry II's assemblies, while only a handful of councils before the 1150s are identified by the sources as territorial or general.

Diplomatic evidence for the Anglo-Saxon period clearly indicates that many of the sessions of the witenagemot must have gathered crowds comparable to Angevin councils (SPELMAN, 1639-1664, v. 1, p. 189-190, 230-231, 317, 324; PIERQUIN, 1913, p. 445-447, 460, 468-471, 482-484, 443-444, 492-494; KELLY, 2001, n. 124, 129) $)^{5}$. The councils of Henry I which assembled at Nottingham in 1109 , Westminster in 1115, Gloucester in 1123, Windsor in 1126, Northampton in 1131, and Winchester in 1133, all gathered groups of bishops and magnates that come close to the size of the largest councils of Henry II. Equally impressive were the multitudes gathered at councils of Oxford and Westminster in 1136, Winchester in 1141 and Westminster in 1153. Only a few assemblies, however, are reported by contemporary sources as having gathered the entire nobility of the kingdom ${ }^{6}$.

Terms such as universitas regni and communitas regni rarely appear in the accounts for the reign of Henry II, but there are at least some references to a group which could be identified as the political community of the kingdom. The trial of Becket, for example, contains references to this group. Not satisfied with a private submission, Henry required the archbishop to assent to the royal constitutions in public at the Council of Clarendon in 1164, a gathering to which the king summoned the entire kingdom with all its prelates and magnates. According to the description in Herbert of Bosham's account, the king

[s]ummoned the entire realm, prelates of the kingdom and magnates. And within a few days, they all assembled at the palace; and there in the presence of all, our archbishop solemnly promised, that he would observe the royal customs in good faith (ROBERTSON, 1875-1885, v. 3 , p. $278-279)^{78}$.

Interestingly, the biographer of Thomas Becket here associates the nobles of England with the entire kingdom, an association which is similarly made by William of Newburgh in reference to the Scottish presence at the Council of York in 1175. Accordingly, the royal summons are described as "universal" for this gathering and also for the Council of Bridgnorth in 1155, all of which appear to have been attended by the political community, meaning here the nobility of the kingdom. According to the chronicler William of Newburgh:

Having come into England, he appointed the city of York for the performance of those stipulations. On his arrival there, in the midst of a great number of his nobles, he met the king of Scots [...]. The king of Scots also before the whole multitude of the nobles of each kingdom, in the accustomed manner acknowledged the king of England as his lord and he himself to be his liege man. He also delivered to him the three principal fortresses of the kingdom, namely, Roxburgh, Berwick, and Edinburgh, as a security (HOWLETT, 1884, p. 198)'. 
The term is also employed in Battle Chronicle in reference to the nobles participating at the Council of Bridgnorth in 1155:

Shortly thereafter the king forced Hugh to surrender. He sent throughout England to the archbishops, bishops, and many abbots, and to all earls and barons, to come to a meeting on the fourth day before the feast of St. Benedict in the summer. When they had all assembled, peace was made between the king and Hugh (SEARLE, 1980, p. 161-162) ${ }^{10}$.

Susan Reynolds explains that in the thirteenth century, the "communitas and its derivates could mean either the whole community, including great men (and in some contexts the king himself), or only the 'common people"' (REYNOLDS, 1984, p. 318).

The phrases totius Anglie and omnes in Anglia were frequently employed in the sources after the 1150s, and appear to be alternatives for universus in the description of the composition of royal councils. It is suggested that these concepts best described those who expected to be summoned rather than those actually in attendance at assemblies. According to Gervase of Canterbury, the princes of the entire kingdom (praesulum et principum totius Angliae) were called to assemble at a council in Wallingford in order to restore peace after Hugh de Mortimer's rebellion, early in 1155 (STUBBS, 1879-1880, v. 1, p. 162). Irritated by Becket's defiance at the Council of Clarendon early in 1164, Henry II called another council to meet in October at Northampton, where according to the account of Ralph of Diceto, "convenerunt illuc episcopi, comites, barones, totius regni, mandato regis urgente” (STUBSS, 1876, v. 1, p. 313-314). The term is again used by Gervase when describing those summoned for the Council of London in 1170 and by the monk of Battle in reference to those

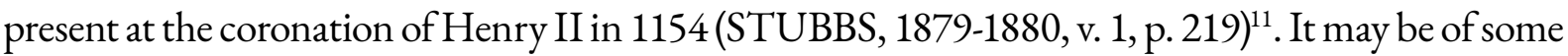
significance that the description of the attendance at a most public event, namely a royal coronation, is similar to that referring to those present at councils.

The Council of Northampton in 1164 is described in the account of William FitzStephen, who reports that "on the second day, when the bishops, earls and all the barons of England ('episcopi, comites, barones Anglie omnes'), as well as many from Normandy, had taken their seats [...] the archbishop was accused of contempt of the Crown" (ROBERTSON, 1875-1885, v. 3, p. 49-58). According to Roger of Howden, in August 1176 the nobles of England all congregated in the city of Winchester ("congregatis omnibus [...] in urbe Wintonia") for a council which put an end to a dispute between the archbishops of Canterbury and York. The following year another assembly gathered in London a multitude so large that it could hardly be counted, "venerunt etiam illuc tot abbates, tot decani, tot archidiaconi, quo sub numero non cadebant. Venerunt etiam illuc comites et barones regni, quorum non est numerus. Et congregatis omnibus in regia apud Lundonias”, just as two months later they all assembled at Geddington and then Windsor to celebrate yet another council, "venerunt autem ibi ad eum fere omnes comites et barones et milites regni" (STUBBS, 1867 , v. 1, p. 118-119, 144-145, 160-161). These chronicle passages are not simply reporting that assemblies were attended by a great number of nobles, but they intend to assert that all the important magnates of the kingdom had been summoned.

The witness lists of English charters granted at assemblies are relatively short and can hardly be a clear indication of the total number of those present at a council, since the names would normally correspond to those particularly concerned with the privilege or donation conceded or close to the king when the charter was drafted. There are, however, a few exceptions, like those lists of witnesses 
incorporated into a treaty with the count of Flanders and grants to the bishop of Lincoln and St Albans Abbey. No such lists are available for the Council of Wallingford in 1155, attended by "praesulum et principum totius Angliae”, according to Gervase of Canterbury (STUBBS, 1879-1880, v. 1, p. 162). The large number of witnesses to the royal constitutions approved at the Council of Clarendon corroborates the general character of the assembly of 1164, which according to Gervase of Canterbury and Ralph of Diceto, was attended by the two archbishops, twelve bishops and nearly forty nobles, including no less than ten earls (STUBBS, 1879-1880, v. 1, p. 178; i. 313-314). Like the gathering at Clarendon, the Council of Northampton in 1164 was also a general assembly, described in the sources as a generale concilium and attended by "episcopis, comitibus, baronibus Anglie omnibus" (ROBERTSON, 1875-1885, v. 1, p. 44; v. 3, p. 49-58; v. 4, p. 134; v. 5, p. 135; MAXWELL, 1906, v. 2, p. 97). However, two letters sent to the king of France - one of which peculiarly describes the meeting as a "plenary council" - , and a charter granted to Sibton Abbey, are contemporary with the meeting of this council, but are nevertheless witnessed by only two testes; hardly an indication of general attendance.

It is clear that witness lists of charters may sometimes help towards deciphering the attendance at councils, but are never a definite indication of how many were actually present at assemblies. The attendance at the Council of London in 1170, for example, is hardly given a territorial character by the very few witnesses in royal charters notifying the settlement between the archbishop of Rouen and the bishop of Nevers, and granting an award to Robert Mantel, both of which appear to be connected with the meeting. It is evident, on the contrary, that this council was attended by a large gathering described by Gervase as "totius Angliae episcopi, abbates, comites, barones vicecomites, praepositi, aldermanni cum fidejussoribus" (ROBERTSON, 1875-1885, v. 7, p. 300). Henry's arbitration between the kings of Castile and Navarre was witnessed by twenty-seven nobles at the Council of London in March 1177. This assembly, however, is described by Roger of Howden as a generale concilium and those present as omnibus in regia, thus indicating that the witness list represents but a portion of those in attendance at the council (STUBBS, 1867, v. 1, p. 144-145; DELISLE; BERGER, 1916-1927, n. 505). Similarly, Roger also reports that a royal council to establish peace and stability in the kingdom brought "omnes comites et barones et milites regni”, to the town of Geddington in May 1177 (STUBBS, 1867, v. 1, p. 160-161). Royal charters to Christ Church Cathedral and St Augustine's Abbey may have been connected with the discussions at this council, but were drafted at Windsor, and testified only by twelve nobles (DEVILLE, 1908, p. 569-570).

According to the chronicler of Battle Abbey, the king "sent throughout England to the archbishops, bishops, and many abbots, and to all the earls and barons” to meet him at the Council of Bridgnorth in 1155: "mandans per Angliam universam archiepiscopos, episcopos et abbatum plurimos, comites et barones universos" (SEARLE, 1980, p. 160-161). In order to be in the presence of his barons at Clarendon in 1164, the king "regnum convocat universum, presules regni et proceres", as stated in the account of Herbert of Bosham, which is also corroborated by Roger of Howden in suggesting that Henry commanded "universis comitibus et baronibus regni" to draft the royal constitutions to be approved at the council. Roger's narrative also gives notice of the presence of "omnibus archiepiscopis et episcopis Angliae" at the Council of Westminster in 1163, a gathering that resembles that at the Council of London in 1170, which according to the Gesta Regis Henrici Secundi, was attended by "omnibus comitibus et baronibus et nobilioribus regni”, and that at the Council of London in 1177, which congregated 
"omnibus in regia". Likewise, the Council of Northampton in 1164 was attended, according to William FitzStephen, by the "episcopis, comitibus, baronibus Anglie omnibus", a multitude similarly described by Ralph of Diceto as "episcopi, comites, barones, totius regni" (ROBERTSON, 1875-1885, v. 3, p. 49-58, 278-279; WHITELOCK; BRETT; BROOKE, 1981, p. 885; STUBBS, 1868-1871, v. 1, p. 220, 221; STUBBS, 1867, v. 1, p. 4-5, 144; STUBBS, 1876, v. 1, p. 313-314).

Like the use of generale concilium, the recurrence of such descriptions should not be reduced to a change in terminology, for the terms used to identify universal attendance were also employed before the 1150s, just as generale concilium was also used to designate gatherings prior to the reign of Henry II. According to the narrative sources, the royal councils at London in 1102, 1107, 1115,1136 , and 1153, Salisbury in 1116, Gloucester in 1123, Windsor in 1126, and Northampton in 1138 , were all attended by the entire body of nobles. Change in terminology then can hardly provide a comprehensive explanation for the multiplication of such descriptions after the $1150 \mathrm{~s}$, and nor can the rhetoric of medieval chronicles.

This is not to suggest that all the king's tenants were always in attendance at royal councils, but that all of those who belonged to the political community of the kingdom were invariably summoned, whether by personal letters or by royal messengers. The template address which often initiates Henry II's charters provides a hint as to who was called to assemblies: "Henricus rex Anglorum et dux Normannorum et Aquitanorum et comes Andegauorum archiepiscopis, episcopis, abbatibus, comitibus, iusticiis, vicecomitibus, baronibus, ministris et omnibus fidelibus suis totius Anglie salute" (MAXWELL, 1906, v. 2, p. 438-439). It is clear that not "all the faithful" of the king were summoned to general consultations, but the archbishops, bishops, earls, barons, as well as the important royal officials were the regular attenders at these gatherings. And although many charters were also addressed to the nobility of Normandy, Aquitaine, Brittany and Anjou, these magnates were rarely in attendance at councils held in England. This is an important consideration, because it is possible that the unprecedented frequency reached by royal councils in this period meant that the nobles residing in England could get together on a regular basis and thus gradually develop a esprit de corp that was accelerated with the loss of Normandy in 1204, and that facilitated corporative action against royal abuses in 1205 and 1215.

A royal council offered perhaps the most appropriate setting for large-scale political and social interaction between the nobles of the kingdom. Just as church councils contributed towards maintaining not only doctrinal but also social cohesion among the prelates, royal assemblies not only served to obtain the adherence of the magnates to royal policy, but they must have also strengthened a sense of community among those present. The concept of a community of the realm may not have been entirely foreign to chroniclers before the reign of Henry II, but the unprecedented regularity with which nobles met each other at councils between 1155 and 1188, effectively turned a concept of political theory into a social reality. It is difficult to believe, therefore, that the same group of barons interacting so regularly in political activity might altogether fail to develop some measure of corporative sentiment. A letter sent by Gilbert Foliot to Becket in 1166 powerfully illustrates the social phenomenon prompted by conciliar activity in this period. The bishop of London reminded the archbishop in exile of the difficult proceedings at the Council of Northampton in October 1164, when "the people assembled as one man, and when all had taken their seats according to their dignity and rank", "conuenit populus ut uir unus"(DUGGAN, 2000, v. 1, p. 515). 
Large assemblies fulfilled an important social role in a world fragmented by local power and by the primitive state of central government. To this point, monarchical governance was exercised primarily by means of itineration, but the enlargement of the Angevin dominions in the second half of the twelfth century and the increase of royal intervention in the localities, were among the factors which contributed towards making councils a regular complement to visitations. The Plantagenets in England from Henry II to John, devoted a great deal of economic and human resources to various military quests which aimed at the dominance of what is now Britain and France. By the end of the reign of Henry II, the Angevin dominions stretched from the Scottish border to the French Pyrenees. David Herlihy has suggested that "nearly all historians are agreed that an underlying phenomenon of the second feudal age was a substantial and continuing growth in population" (HERLIHY, 1970, p. 34) Pressing administrative and financial demands prompted by expanding territories and the new complexities generated by distant dominions, economic and demographic explosions, eventually effected the sedentarisation of the royal court, the treasury and the Exchequer.

In the twelfth century, rulers and their courts kept on the move, but an institutional alternative to governing by visitation was provided by the consolidation of territorial assemblies. Robert Bartlett, in his recent study of the government of the Norman and Angevin kings in England, explains that for the household court "an alternative to visiting every corner of the kingdom was to bring men from every corner of the kingdom to a great assembly" (BARTLETT, 2000, p. 143) ${ }^{12}$. Desiré Pasquet argues that this political transformation is evidently manifested in the king's efforts to bring all his subjects under his direct authority, a desire that went as far as initiating the destabilisation of the entire feudal framework. In his essays on the origins of the House of Commons, Pasquet explains that this destabilisation was concretised by royal policies which practically abolished the distinction between tenants-in-chief and sub-vassals. In other words, the king's attempt to centralise government was transforming feudal vassals into subjects of the crown.

In reference to the first parliamentary assemblies in the thirteenth century, Edward Miller has suggested, moreover, that

among the features which characterise early parliaments we may not ignore the habit of bringing the whole governmental force of England into a focus, the habit of concentrating intense administrative activity on the part of all the officials and offices of the king's government in one place and at the same time (MILLER, E., 1967, p. 10) ${ }^{13}$.

In a period when governance was entangled between the growth of institutional structures and the strengthening of territorial kingship, the consolidation of conciliar consultation and the presence of the universitas regni at assemblies, dramatically reversed traditional methods and ceased to take the monarch to the kingdom by bringing the kingdom to the monarch. Councils facilitated centrifugal and centripetal governance: the participation of the nobles kept the king in touch with and sensible to regional affairs, and the nobles aligned with the measures of central government. In addition, these meetings prompted social contact between people separated by distance and difficult communications, and thus probably assisted the consolidation of a community of the realm.

The reign of Henry II witnessed nothing like Magna Carta, not because of the inexistence of a communitas regni or a baronagium which could have reacted corporatively against royal abuses, but mainly because unlike his son, Henry had not given them enough reasons for doing so. The extent to 
which consensual politics and cooperative governance developed in this period is not characteristic of a community obliged by ceremonial compliance, but it is a phenomenon mainly associated with the regularity of conciliar activity and a credit to Henry's ability in managing the barons.

While the attendance at English assemblies varied throughout the twelfth century with the incorporation of influential subjects other than the lay and ecclesiastical magnates and the officials of the curia regis, the composition of royal assemblies remained practically unchanged, for they all intended to assemble the political community or the universitas regni. The unprecedented regularity with which this group assembled from 1155 to 1188 assisted the development and consolidation of communal feeling and corporate action, either in cooperation with royal government - a characteristic feature during the reign of Henry II — or against the king, as happened a few decades later. Royal councils often witnessed fierce disputes and antagonism between the monarch and his powerful vassals, but Henry skillfully exercised his authority to lead the proceedings to his advantage and turn these meetings into occasions characterised by consensual politics and cooperative governance.

Assembled as one man, the entire kingdom was brought to Henry's presence at royal councils, thus offering the monarch a unique opportunity to have his policies and measures discussed and consented to by the nobles, and subsequently enforced throughout England by a body of loyal and able officials, many of whom were also present at these meetings. The king thus summoned councils with considerable frequency for he seems to have realised the administrative, financial and political benefits offered by the assemblage of the universitas regni and the new professionals, the advice of whom greatly enriched conciliar discussions as well as developing the competence to deal with a variety of matters.

\section{References}

BARTLETT, R. England under the Norman and Angevin Kings 1075-1225. Oxford: Oxford University Press, 2000. BUTT, R. A History of Parliament: the Middle Ages. London: Constable, 1989.

CRONNE, H. A.; DAVIS, R. H. C. (ed.). Regesta Regum Anglo-Normannorum. Oxford:Oxford University Press, 1968. v.3.

DELISLE, L.; BERGER, E. (ed.). Recueil des Actes de Henri II, Roi d'Angleterre et Duc de Normandie. Paris: Imprimiere Nationale, 1916-1927. $4 \mathrm{v}$.

DEVILLE, E. Inventaire sommaire d'un fragment de cartulaire de l'abbaye du Bec conservé à la Bibliothèque nationale. Paris: Champion, 1908.

DUGGAN, A. (ed.). The Correspondence of Thomas Becket. Oxford: Oxford University Press, 2000. 2 v.

HERLIHY, D. The History of Feudalism. London: Macmillan, 1970.

HODY, H. A History of English Councils and Convocations. London: Clavel, 1701.

HOLT, J. The Prehistory of Parliament. In: DAVIES, R. G.; DENTON, J. H. (ed.). The English Parliament in the Middle Ages. Manchester: Manchester University Press, 1981. p. 1-28.

HOWLETT, R. William of Newburgh, Historia Rerum Anglicarum, Chronicles of the Reigns of Stephen, Henry II, and Richard I. London: Rolls Series, 1884. v.1.

JOHNSON, C.; CRONNE, H. A. (ed.). Regesta Regum Anglo-Normannorum. Oxford:Oxford University Press, 1956 . v. 2.

KELLY, S. E. Anglo-Saxon Charters, Abingdon. Oxford: British Academy, 2001. v. 2.

KING, E. (ed.). William of Malmesbury, Historia Novella. Oxford: Oxford University Press, 1998.

LUARD, H. R. (ed.). Matthew Paris, Matthaei Parisiensis Chronica Majora. London: Longmans, 1872-1884. 7 v. 
LYON, B. Constitutional and Legal History of Medieval England. New York: Harper and Row, 1960.

MAGNUSSON, E. (ed.). Thómas Saga Erkibyskups. London: Rolls Series, 1875. 2 v.

MAITLAND, F. Bracton's Notebook: a Collection of Cases Decided in the King's Courts During the Reign of Henry the Third. London: Rolls Series, 1887. v. 1.

MAXWELL, H. C. et al. (ed.). Calendar of the Charter Rolls: Preserved in the Public Record Office. London: Stationary Office, 1906. v. II.

MCGURK, P. (ed.). Chronicon Johannis Wigornensis: Chronicle of John of Worcester. Oxford: Oxford University Press, 1998. v. 2.

MILLER, E. The Origins of Parliament. London: Historical Association, 1967.

MILLER, S. T. J. The Position of the King in Bracton and Beaumanoir. Speculum, Chicago, v. 31, n. 2, p. 263-296,1956.

MYERS, A. R. Representation as a European Tradition. History Today, Amsterdam, v. 5, p. 383-390, 1955.

OLESON, T. The Witenagemot in the Reign of Edward the Confessor. London: Geoffrey Cumberlege, 1955.

PIERQUIN, H. Les Annales et Conciles de l'Eglise d'Angleterre pendant la Periode Anglo-Saxonne. Paris: Picard, 1913.

RADDING, C. The Origins of Bracton's Addicio de Cartis. Speculum, Chicago, v. 44, n. 2, p. 239-246, 1969.

REYNOLDS, S. Kingdoms and Communities in Western Europe. Oxford: Oxford University Press, 1984.

RICHARDSON, H. G. The Commons in Medieval Politics. Transactions of the Royal Historical Society, v. 28, p. 21-45, 1946 .

RICHARDSON, H. G.; SAYLES, G. O. The Functions of the Medieval Parliament of England. London: Hambledon Press, 1989.

RICHARDSON, H. G.; SAYLES, G. O. Parliaments and Great Councils in Medieval England. Law Quarterly Review, London, v. 56, p. 1-49, 1977.

ROBERTSON, J. C. (ed.). Materials for the History of Thomas Becket. London: Rolls Series, 1875-1885. 7 v.

RULE, M. (ed.). Eadmer, Historia Novorum in Anglia. London: Rolls Series, 1884.

SAWYER, P. (ed.). Anglo-Saxon Charters. London: Royal Historical Society, 1968.

SEARLE, E. (ed.). Chronicon Monasterii de Bello: The Chronicle of Battle Abbey. Oxford: Oxford University Press, 1980.

SPELMAN, H. Concilia, Decreta, Leges, Constitutiones in Re Ecclesiarum Orbis Britannici. London: Badger, 1639-1664. $2 \mathrm{v}$.

STENTON, F. Anglo-Saxon England. Oxford: Clarendon Press, 1971.

STUBBS, W. (ed.). Gervase of Canterbury, Gervasii Monachi Cantuariensis Opera Historica. London: Rolls Series, 1879-1880. 2 v.

STUBBS, W. (ed.). Radulfi de Diceto Opera Historica. London: Rolls Series, 1876. 2 v.

STUBBS, W. (ed.). Roger of Howden, Chronica Rogeri de Hovedene. London: Rolls Series, 1868-1871. 4 v.

STUBBS, W. (ed.). Roger of Howden, Gesta Regis Henrici Secundi Benedicti Abbati. London: Rolls Series, 1867. $2 \mathrm{v}$.

THOMAS, J. T. E. (ed.). Guernes de Pont-Sainte-Maxence, La Vie de Saint Thomas de Canterbury. Louvain: Peeters, 2002. v. I.

TIERNEY, B. Bracton on Government. Speculum, Chicago, v. 38, n. 2, p. 294-317, 1963.

WHITELOCK, D.; BRETT, M.; BROOKE, C. N. L. (ed.). Councils and Synods with Other Documents Relating to the English Church. Oxford: Oxford University Press, 1981. 2 v.

WOODBINE, G. E. (ed.). Henry de Bracton, De Legibus et Consuetudinibus Angliae, On the Laws and Customs of England. Translated by S. E. Thorne. Cambridge: Harvard University Press, 1968-1977. 4 v. 


\section{Endnotes}

${ }^{1}$ Original text: “[S]i autem princeps vel rex vel alius qui superiorem non habuerit nisi deum, contra ipsum nuon habebitur remedium per assisam, immo tantum locus erit supplicattioni ut factum suum corrigat et emendet, quod si non fecerit, sufficiat ei pro poena quod deum expectet ultorem, qui dicit, mihi vindictam etego retribuam, nisi sit qui dicit quod universitas regni et baronagium suum hoc facere posit et debeat in curia ipsius regis".

${ }^{2}$ See also S. Miller (1956, p. 265-266), Richardson (1946, p. 22-25), Richardson and Sayles (1977, p. 8), Radding (1969, p. 239), Tierney (1963, p. 303, 309, 314) and Maitland (1887, v. 1, p. 32-33).

${ }^{3}$ See also Oleson (1955, p. 91-101), Spelman (1639-1664, v. 1, p. 189-190, 230-231, 317, 324), Pierquin (1913, p. 445-447, 460, 468-471, 482-484, 443-444, 492-494), Kelly (2001, n. 124, 129) and Sawyer (1968, n. 22, 90, 168, 876, 937; 1428b, 1430a, 1431a, 1436, 1438, 1439).

${ }^{4}$ The Old English term "thegns" or "thanes" was used to refer to the nobles and landowners second in rank to the earls in the Anglo Saxon kingdoms, so they represented the bulk of the aristocracy in England prior to the Norman Conquest.

${ }^{5}$ See also Sawyer (1968, n. 22, 90, 168, 876, 937, 1428b, 1430a, 1431a, 1436, 1438, 1439).

${ }^{6}$ See also McGurk (1998, p. 102, 138, 168), Rule (1884, v. 4, p. 231, 237), King (1998, p. 6), Johnson and Cronne (1956, n. 918), Cronne and Davis (1968, n. 928), Spelman (1639-1664, v. 1, p. 189-190, 230-231, 317, 324), Pierquin (1913, p. $445-$ $447,460,468-471,482-484,443-444,492-494)$ and Kelly (2011, n. 124, 129).

${ }^{7}$ Original text: “[...] regnum convocat universum, presules regni et proceres. Et infra dies paucos conveniunt universi, ubi in omnium conspectu et primus ante omnes archipresul in pretacta forma se obligat, quod videlicet regias consuetudines foret observaturus bona fide [...]".

${ }^{8}$ See also Whitelock, Brett and Brooke (1981, p. 885).

${ }^{9}$ Original text: “Veniensque in Angliam, apud Eboracam metropolim eorundem celebrationem pactorum instituit. Quo cum venisset optimatum suorum vallatus frequentia, prout condictum erat, occurrit ei rex Scottorum cum universis regni sui nobilibus [...]. Ipse quoque rex Scottorum coram universa multitudine nobilium utriusque regni regem Anglorum modis sollemnibus dominum suum seque hominem et fidelem ejus declaravit; eique tria praecipua regni sui munimina, scilicet Rokesburg, Berewic, Castellum Puellarum, loco obsidum tradidit".

${ }^{10}$ Original text: “Haut multo postmodum tempore rex ipsum Hugonem ad deditionem coegit, mandans per Angliam universam archiepiscopos, episcopos et abbatum plurimos, comites et barones universos, quarto die precedente festum sancti Benedicti estivi temporis ibidem convenire. Quibus congregatis, pax inter regem et Hugonem facta est".

${ }^{11}$ See also Searle (1980, p. 152).

${ }^{12}$ See also E. Miller (1967, p. 10).

${ }^{13}$ See also Holt (1981, p. 4-6). 